\title{
POSSIBLE TSUNAMI ALONG THE NORTHWESTERN COAST OF THE UNITED STATES INFERRED FROM INDIAN TRADITIONS
}

\author{
By Thomas H. Heaton and Parke D. Snavely, JR.
}

Subduction of the Juan de Fuca and Gorda plates beneath western North America presents a paradox; despite the fact that there is good evidence of 3 to $4 \mathrm{~cm} / \mathrm{yr}$ of ongoing convergence, there is a remarkable paucity of either historic or instrumentally recorded shallow subduction earthquakes. Steady aseismic slip along the entire Cascadia subduction zone provides one explanation for this seismic quiescence. However, the Cascadia subduction zone shares many features, including temporal quiescence, with other subduction zones that have experienced very large shallow subduction earthquakes (Heaton and Kanamori, 1984). Yet, there is no direct geologic or historical evidence presently available to confirm that great shallow subduction earthquakes have occurred along the coast of Washington, Oregon, and northern California. However, there are reports describing Indian legends of great sea-level disturbances that may be related to large nearby earthquakes. In this letter, we briefly review the history of exploration and settlement of this region by nonnative people and then discuss legends from Indians in northern Washington and northern California.

The coastline of Washington was first explored by Captain Bruno Heceta of Spain in 1775, and a Spanish settlement was briefly occupied (5 months) in 1792 at Neah Bay (see Figure 2). This coastline was also explored by Captain James Cook (England) in 1778 and Captain Robert Gray (United States) in 1792. Fur trading settlements were established by Canadians in 1810 and 1811 at Spokane, Astoria, and Fort Okanogan. Permanent, but sparse, settlement of the region persisted until the 1850's when a major wave of immigration occurred.

It seems certain that great coastal subduction earthquakes have not occurred since the 1850's and highly probable that they have not occurred since the 1790's. However, Judge James Swan has reported curious Indian "traditions" that suggest effects that could have resulted from a great shallow subduction earthquake. Swan was a renowned student of Indian lore, writing several fascinating accounts of his experiences with coastal Indians from Washington, Oregon, and British Columbia during the 1850's through 1870's (Swan, 1857, 1868, 1874).

The following excerpts are from Swan's 1868 publication, "The Indians of Cape Flattery." Although it is useful to study a large quantity of Swan's writings in order to better understand the context of the "traditions" of a large sea-level disturbance, the first excerpt indicates Swan's impressions of the reliability of Indian legends.

History, Traditions, Etc.-The history of this tribe (Makah), as far as their knowledge extends, is a confused mass of fables, legends, myths, and allegories. Nothing that they can state prior to the existence of a few generations back is clear or wholly to be relied upon. There are a few prominent events that have been remembered as having occurred; but the detail is confused, and it is very rare that two Indians tell the same story alike, unless it may be some wild and improbable legend, like the fairy tales related in nurseries, which are remembered in after life. A notable instance of this unreliability is in their version of the account of the 
Spanish settlement attempted at Neeah Bay by Lieut. Quimper, in 1792 by order of the commandant of the Spanish forces at Nootka. All they really know about it, is that they have been told by their fathers that the Spaniards were here, and they can point out the locality where yet may be found pieces of tile used by the Spaniards in building. But although that occurrence was only seventy-three years ago, there is but one man living in the tribe who remembers the circumstances, and he is in his dotage. Almost every Indian I have questioned upon the subject gives a different version of the detail. Now, as they cannot relate correctly matters given in our history, and of a comparatively recent date, but little dependence can be placed upon the tales of their origin, which are interesting only for their fabulous and superstitious nature.

More recent events, such as the murder of the crews of the ship Boston, in 1803, and of the Tonquin, in 1811, and the captivity of Jewett among the Nootkans, they remember hearing about, and relate with tolerable accuracy. As events recede in years, however, they become obscured with legends and fables, so that the truth is exceedingly difficult to discover.

Keeping these strong caveats in mind, we now reprint Swan's (1868) account of Indian "traditions" of a great sea level disturbance along the coast of Washington. Geographic locations of tribes and places mentioned in this account are shown in Figures 1 and 2 (modern spelling of some words may differ from that in the account). In addition, the word, Makah, is used by eastern inland Indians and nonnative people; the word, Classet, is used by northern Coastal Indians, and the word Kwenaitchechat is used by Cape Flattery Indians (Makahs). All of these words have the same meaning: "people who live on a point of land projecting into the sea (i.e. Cape Flattery)."

The only tradition that I have heard respecting any migratory movement among the Makahs, is relative to a deluge or flood which occurred many years ago, but seems to have been local, and to have had no connection with the Noachic deluge which they know nothing about, as a casual visitor might suppose they did, on hearing them relate the story of their flood. This I give as stated to me by an intelligent chief; and the statement was repeated on different occasions by several others, with a slight variation in detail.

"A long time ago," said by informant, "but not at a very remote period, the water of the Pacific flowed through what is now the swamp and prairie between Waatch village and Neeah Bay, making an island of Cape Flattery. The water suddenly receded leaving Neeah Bay perfectly dry. It was four days reaching its lowest ebb, and then rose again without any waves or breakers, till it had submerged the Cape, and in fact the whole country, excepting the tops of the mountains at Clyoquot. The water on its rise became very warm, and as it came up to the houses, those who had canoes put their effects into them, and floated off with the current, which set very strongly to the north. Some drifted one way, some another; and when the waters assumed their accustomed level, a portion of the tribe found themselves beyond Nootka, where their descendants now reside, and are known by the same name as the Makahs in Classett, or Kwenaitchechat. Many canoes came down in the trees and were destroyed, and numerous lives were lost. The water was four days regaining its accustomed level." 
The same tradition was related to be by the Kwilleyutes, who stated that a portion of that tribe made their way to the region in the vicinity of Port Townsend, where their descendants are known as the Chemakum tribe. I have also received the same tradition from the Chemakum Indians, who claim to have originally sprung from the Kwilleyutes. There is no doubt in my mind of the truth of this tradition. The Waatch prairie shows conclusively that the water of the Pacific once flowed through it; and on cutting through the turf at any place between Neeah Bay and Waatch, the whole

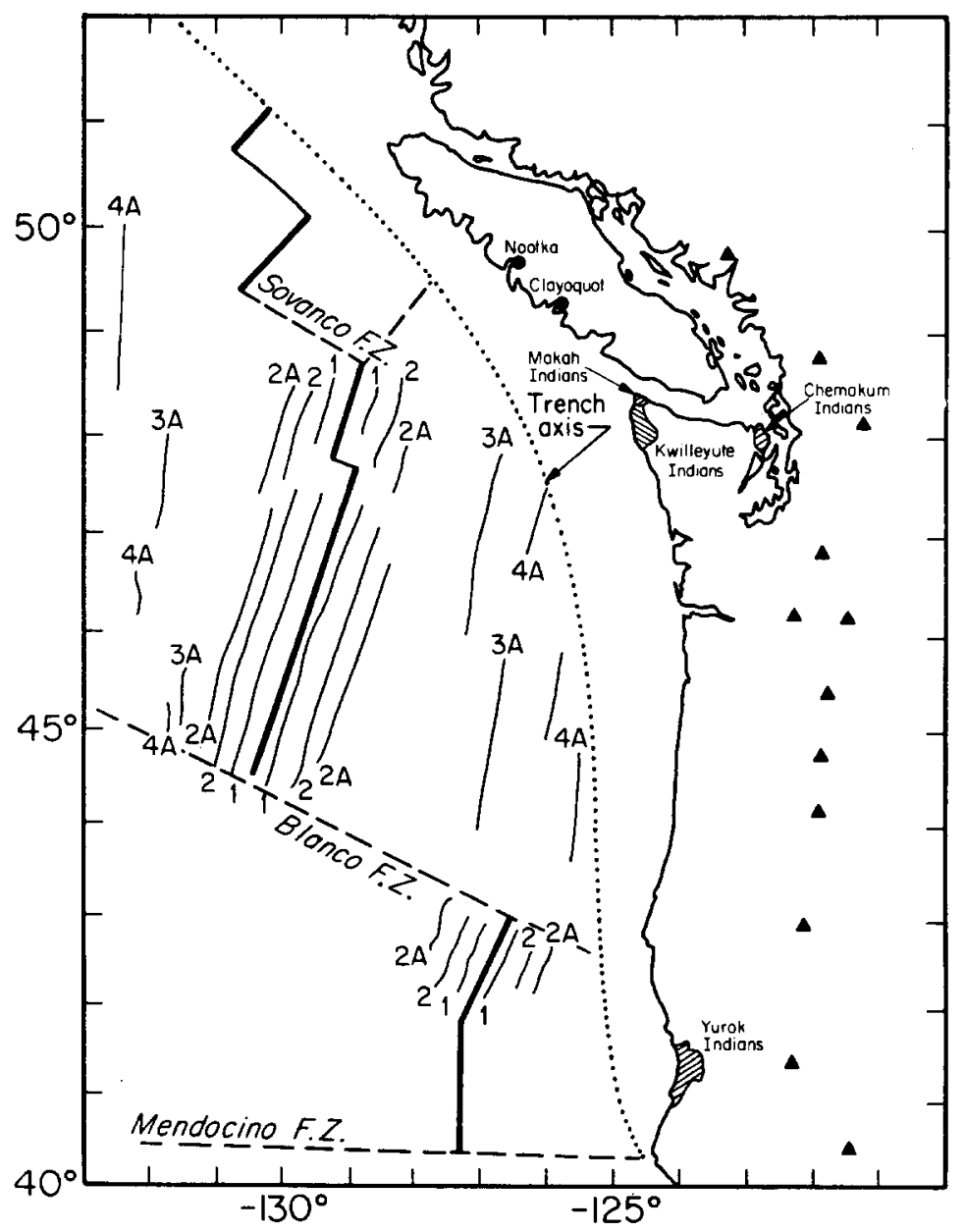

FIG. 1. Approximate location of Indian tribes and place names mentioned in this report. Approximate locations of sea-floor magnetic lineations and Quaternary volcanoes (triangles) are also shown.

substratum is found to be pure beach sand. In some places the turf is not more than a foot thick; at others the alluvial deposit is two or three feet.

As this portion of the country shows conclusive evidence of volcanic action, there is every reason to believe that there was a gradual depression and subsequent upheaval of the earth's crust, which made the waters rise and recede as the Indians stated. Fossil remains of whales are said by the Indians to be found around a lake near Clyoquot, which were possibly deposited at the time of this flood. I have not seen these remains, but I 


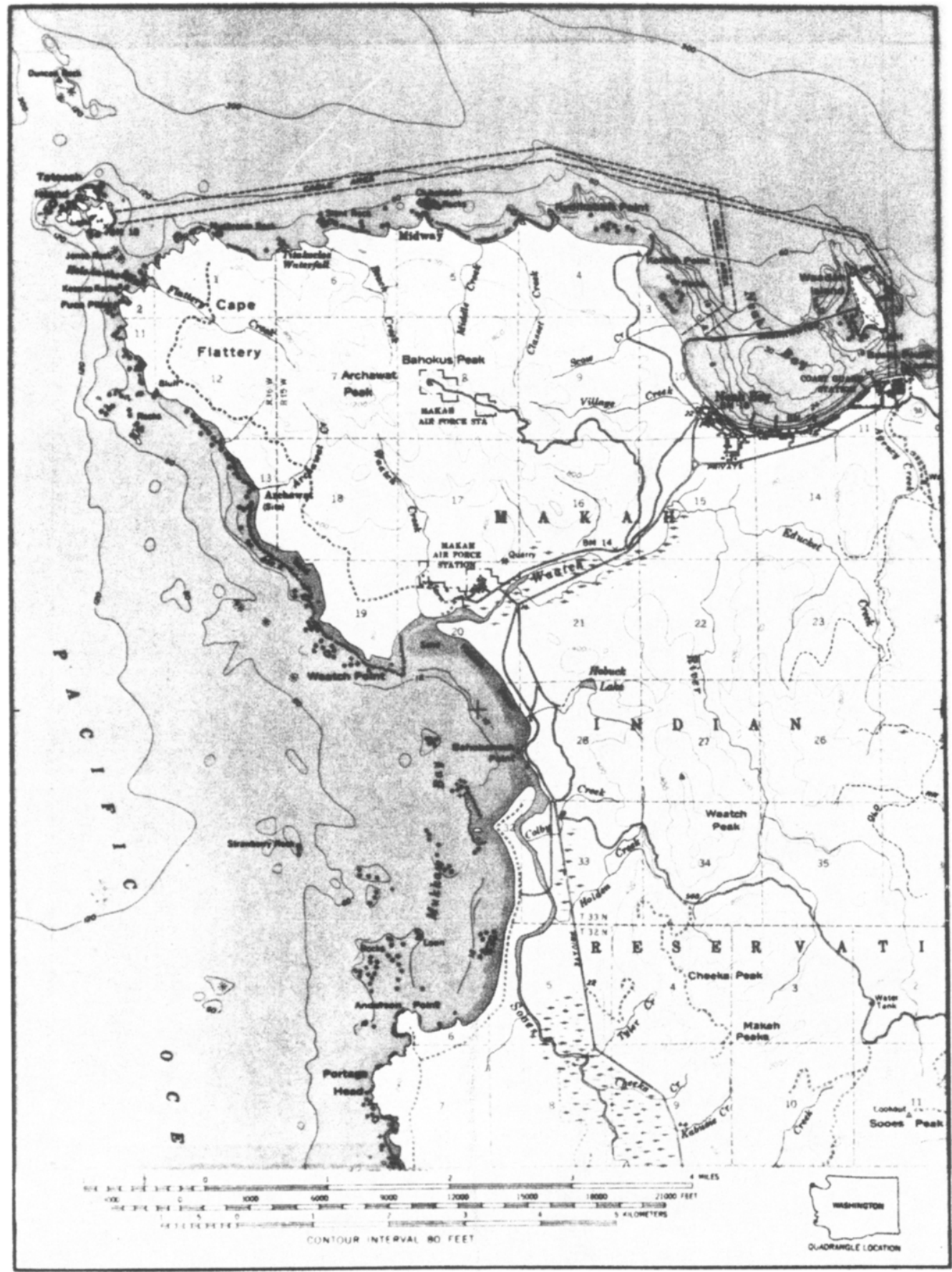

FIG. 2. Topographic map of the Cape Flattery region (U.S. Geological Survey Cape Flattery Quadrangle, 15-min series).

have been told of their existence by so many different Indians who professed to have seen them, that I think the story probably correct. The Indians do no think they got there by means of the flood, but that, as before stated, they are the remains of the feasts of the T'hlukloots, or thunder bird, who carried the whales there in his claws, and devoured them 
at his leisure. With the single exception of this legend of the flood, I have never learned from them that they have any tradition respecting the tribe coming to or going from the place where they now reside, and this is the only one which they relate of ancient times that is corroborated by geological or other evidence.

Could this be an account of a great tsunami? Although there are many features of this report that seem exaggerated, apparently Swan was convinced that some remarkable sea-level disturbance had occurred. He clearly segregates this report from the majority of legends which he feels are of a more mythical nature. The words, "a long time ago, but not at a very remote period," indicate that the alleged disturbance predates the lifetimes of the reporting Indians, but was not to be confused with an ancient time which was associated with the great majority of their mythical legends.

If this is an account of an ancient tsunami, then what can be deduced about its nature and origin? Great tsunamis may have periods of tens of minutes to hours, but 4 days is without percedent. If we are to believe that this is an account of a through the years. If the event is real, then it is apparent that the effects must have been substantial. However, it seems incredulous that any tsunami could have overtopped the entire Cape Flattery region since the highest elevation of the cape exceeds $400 \mathrm{~m}$. Furthermore, one is hard pressed to explain why the water would become warm. Nevertheless, the description of water receding from Neah Bay and then returning in a strong current is clearly suggestive of a tsunami.

If this is a tsunami description, could the sea wave have originated from a great earthquake at a distant location? Since there is no mention of any ground shaking, this might be a logical conclusion. However, large historical earthquakes along the Pacific rim have not generated large tsunamis at Neah Bay. The $M_{w} 9.2$ Alaskan earthquake in 1964 caused a tsunami of only about $1.3 \mathrm{~m}$ at Neah Bay (Cloud and Scott, 1972). Furthermore, the story indicates that Cape Flattery was an island before this legendary event. This may be plausible since a low marshy area between Waatch and Neah Bay is the only thing that currently prevents Cape Flattery from being an island. If there was permanent uplift of the Waatch lowland associated with the event described in the legend, then crustal deformation associated with a nearby subduction earthquake could explain the uplift. However, this and any other conjectures about the significance of this legend are purely speculative. There are enough inconsistencies in the legend that one must seriously consider the interpretation that this Indian tradition may be entirely fictional. Nevertheless, it is noteworthy that such a report exists for a region for which there is growing concern that large subduction earthquakes and subsequent tsunamis may be a real possibility.

We have mentioned this report by Swan to several colleagues and this resulted in the rediscovery of other Indian legends of earthquake activity along the northwestern coastal United States. Gary Carver (Department of Geology, Humbolt State University, Arcata, California) informed us of myths of the Yurok Indians in which earthquakes seem to play a prominent role. These myths were recorded by A. L. Kroeber (1976) between 1900 and 1907. Yurok Indians inhabited the region that roughly coincides with Redwood National Park in northernmost coastal California (see Figure 1). According to Yurok mythology, the god, Earthquake, was a very powerful being that ran over the earth, shaking and tearing the ground, breaking trees, and disturbing the rivers and ocean. However, the Yurok stories are very 
allegorical and seem to be correctly classified as myths. We do not reproduce these myths here since they are somewhat lengthy, difficult to interpret, and their factual basis is unknown.

\section{CONCLUSIONS}

We thank Gary Carver for generously providing materials relating to Yurok Indian mythology. We also thank Joseph Ziony and Robert Wallace for thoughtful reviews of the manuscript. This work is supported, in part, by the U.S. Nuclear Regulatory Commission.

\section{REFERENCES}

Cloud, W. K. and N. H. Scott (1982). Distribution of intensity, in The Great Alaska Earthquake of 1964, Seismology and Geodesy, National Academy of Sciences, Washington, D.C., 65-108.

Heaton, T. H. and H. Kanamori (1984). Seismic potential associated with subduction in the northwestern United States, Bull. Seism. Soc. Am. 74, 933-941.

Kroeber, A. L. (1976). Yurok Myths, University of California Press, Berkeley, California, $488 \mathrm{pp}$.

Swan, J. G. (1857). The Northwest Coast, Harper and Brothers, Publishers, New York, 435 pp.

Swan, J. G. (1868). The Indians of Cape Flattery, at the entrance to the straight of Juan de Fuca, Washington Territory, Smithsonian Contributions To Knowledge, 220, $108 \mathrm{pp}$.

Swan, J. G. (1874). The Haidah Indians, of the Queen Charlotte Islands, British Colombia, Smithsonian Contributions To Knowledge, 267, 25 pp.

U.S. Geological SuRvey

Seismological Laboratory

California InstituTE OF TECHNOLOGY

Pasadena, California 91125 (T.H.)

Manuscript received 8 May 1985
U.S. Geological SURVEY 345 MidDlEFIELD ROAD Menlo Park, California 94025 (P.S.) 